\title{
Clergy Who Leave Congregational Ministry: A Review of the Literature
}

\author{
Allison K. Hamm, ThD* \\ Duke Divinity School \\ Duke University \\ David E. Eagle, $\mathrm{PhD} * *$ \\ Duke Global Health Institute \\ Duke University
}

\begin{abstract}
Allison Hamm, Th.D., is a recent graduate and Adjunct Professor of Theology and Religion at Duke Divinity School, where her interdisciplinary research focused on the depiction of speech in the Hebrew Bible as a powerful force in the formation and destabilization of human communities. She is interested in how ancient questions about life and the human experience can enrich and expand contemporary ways of thinking about work, community, politics, and living a good life.
\end{abstract}

David Eagle, $\mathrm{PhD}$ is Assistant Research Professor in the Global Health Institute at Duke University. His research is motivated by a desire to improve the state of religious clergy in contemporary settings and understand the factors that help congregations thrive. Other research interests include how the changing religious landscape in North America is impacting theological education, congregations and religious leaders.

Accepted for publication in the Journal of Psychology and Theology

*allison.k.hamm@gmail.com

**Corresponding author. 310 Trent Drive, Durham, NC 27708, david.eagle@ duke.edu. 


\section{Abstract}

Since its inception in the 1960 s, research on premature (pre-retirement) clergy attrition from congregational ministry has focused on identifying the factors that precipitate and mitigate ministry exits, while the rates at which clergy leave the ministry have been inconsistently tracked. The literature on clergy attrition is peppered with claims of alarmingly high rates of departure, however, these studies lack strong empirical support. The evidence, while fragmentary, consistently shows that pastors do not leave congregational ministry in large numbers. Incidence of attrition of about 1-2 percent per year is typical across Protestant denominations and among Roman Catholic priests. In addition, contrary to popular conceptions, there is little evidence attrition is particularly high in the first 5 years of congregational ministry. In terms of the reasons for leaving, among Protestants, the most common factor named is conflict with the congregation or denominational system; a smaller number leave to pursue personal goals or to care for family. Among Catholics, loneliness and isolation, tied in major part to the celibacy requirement, are the most significant reasons cited for leaving. Finances or a loss of faith are rarely cited as reasons for leaving among either Catholics or Protestants. 


\section{Introduction}

Alarmist reports detailing a crisis in pastors who are leaving congregational ministry abound. Some have reported five-year attrition rates of up to 85 percent (Stewart, 2009, p. 112); others have estimated that every six minutes a pastor is fired (Rediger, 1997, p. 8). While many of these claims border on the absurd — it is highly unlikely that 87,600 are being fired every year (i.e. one every six minutes) — many of these alarmist statistics persist because there is no comprehensive summary and synthesis of research on clergy attrition. The purpose of this article is to address this gap and summarize what we know and do not know about premature (i.e. pre-retirement) clergy attrition from congregational leadership positions. Our goal is to answer several basic questions. How many pastors leave congregational ministry before retirement? What are the factors that contribute positively or negatively to persistence in church leadership? What steps can be taken at the educational and organizational levels to support positive occupational outcomes for clergy? This review focuses on clergy who leave pastoral ministry before retirement. The topic of clergy supply and demand and the degree to which there is a labor shortage (as is clearly the case in the Roman Catholic Church, cf. M. L. Gautier et al., 2012) or surplus of congregational leaders is beyond the scope of this review. Even though clergy appear more likely to leave congregational ministry for another form of ministry, because the data on attrition is scarce, we do not make a distinction between leaving congregational ministry for another career all together or leaving for another noncongregational ministry position (Transition into Ministry, 2021).

Interest in these questions is not new. Research on attrition and retention among clergy began in earnest in the 1960s, when the earliest studies explored the effects of broad cultural shifts— such as increasing secularization and an erosion of trust in authority — on the nature of ministry and its challenges (Hoge \& Wenger, 2005). Developments in social science and occupational research have since expanded the range of inquiry to include studies ranging from the analysis of which personality factors or predispositions might be best suited to ministry, to the investigation of the contextual and social factors that play direct or indirect roles in the clergy experience. While research on priests and pastors has 
produced a robust literature, the picture that has emerged of pastoral attrition from congregational positions, its causes, and its effects remains hazy: only a rough outline exists, with a few scattered areas of detail and clarity. Reporting on the leadership situation in American religion in 2001, Wind and Rendle observed that "there is no coordinated, systematic research base from which to draw specific conclusions...there are many pieces of evidence, but they are of uneven quality and do not fully cover the areas of inquiry" (2001, p. 2). Almost twenty years later, what was true of research on attrition in American religious leadership then remains true: There is no coordinated, systematic research base from which to prove or disprove popular perceptions of the pastoral profession as beleaguered, disillusioned, and/or sinking into irreversible decline.

Gaining a sense of how many clergy actually leave congregational ministry each year, why and at what stage of their careers they leave, and what the process of these transitions is like requires piecing together data from many different sources and contexts, extrapolating where there are holes in the research and often relying on studies that are only obliquely related to the question of attrition. In what follows, we take a comprehensive look at the literature surrounding clergy attrition in order to provide an update on what is currently known and identify areas where further study is needed. This is a crucial first step in helping congregations, denominational boards, and seminaries evaluate educational and professional support systems in order to improve occupational outcomes for clergy and strengthen local congregations (Woolever, 2012).

\section{Method}

To accomplish this task we conducted a search for recent data on pastoral attrition by searching ProQuest Central, PubMed (for attrition data related to studies of clergy health), Google Scholar, and the databases of the Pew Research Center, Hartford Institute for Religion Research, the Center for Applied Research in the Apostolate (CARA), the Baylor Institute for Studies of Religion (ISR), the Association of Religious Data Archives (ARDA), the National Congregations Study, the Public Religion Research Institute (PRRI), the Association of Theological Schools (ATS), the Barna Group, and Lifeway Research using the 
key words "clergy/pastoral/priest attrition," "leaving church/parish ministry/the priesthood," “clergy/pastoral burnout," "clergy/pastoral resilience," "pastors/priests who quit," and "priest resignations/defections." In addition to these sources, the following denominational websites were individually searched using the same keywords: Presbyterian Church (U.S.A.), United Methodist Church, the Episcopal Church, Evangelical Lutheran Church of America, Lutheran Church (Missouri Synod), the Southern Baptist Convention, and the Anglican Church in North America. The selection of these denominations, although somewhat arbitrary, covered many of the major groups in the United States. It quickly became apparent that denominational websites rarely have any publicly available data on personnel, and we decided not to search any additional denominational sources. We were particularly interested in new sociological studies to have emerged in the past ten years, either qualitative or quantitative, but the lack of recent research required us to go further back in time to get a satisfactory sense of where things stand. We did not limit our search to studies conducted in the United States but found that the situation in the United States is vastly overrepresented in the literature. Where studies from outside the United States were found, they are discussed.

Our focus is on clergy who choose to leave before retirement in both Protestant denominations and the Roman Catholic Church. We discuss the research on Protestant ministers and Catholic priests separately, since the historical, institutional, and ministerial contexts and factors related to attrition vary significantly. It is useful to gain a basic sense of the two bodies of literature on their own terms before considering any resonance between them. We begin by discussing what we call the alarmist statistics around clergy attrition. Then, we turn to research that is backed by more solid evidence and explore rates of attrition among Protestant and Catholic clergy, followed by a discussion of the factors related to premature exit from the profession (again, separately for Protestant and Roman Catholic clergy) before concluding with a brief summary of what the literature indicates about the future of research.

\section{Results}

\section{Alarmist Statistics}


Any foray into the research on clergy attrition is likely to be met with alarming statistics - mostly centered around Protestant clergy and backed by very thin empirical evidence. A widely circulated 1999 article in the Los Angeles Times reported that "roughly 30 percent to 40 percent of religious leaders eventually drop out of the ministry" and "about 75 percent go through a period of stress so great they consider quitting" (Dirmann, 1999). For more than fifteen years these staggering statistics have echoed through popular perceptions of the situation in religious leadership, reappearing over and over again and at times gaining momentum with allusions to reliable bodies of research: "Clergy losses are massive," authors on the website for the Ministering to Ministers Foundation stated, "according to studies by the Alban Institute and Fuller Seminary, 50 percent of ministers drop out of ministry within the first five years and many never go back to church again... A Duke University study found that 85 percent of seminary graduates entering the ministry leave within five years and 90 percent of all pastors will not stay to retirement" (Ministering to Ministers Foundation, Inc., 2016; the origins of these statistics appears to be Stewart, 2009).

A major problem with these studies is they cannot be traced to verifiable studies of clergy. One of the most frequently cited sources is Meek et al. (2003, p. 339), which references "a survey administered through the Fuller Institute of Church Growth" described in Headington (1998). Headington writes that in a 1991 survey of 300 ministers, "50 percent of those who go into full-time service drop out in 5 years" (1998, p. 1), but the survey itself does not appear to have been published; no further information about the sample size, demographics of respondents, or methodology of the study is provided. ${ }^{1}$ Similarly, the 85 percent attrition rate said to have been reported in studies from the Alban Institute and Duke University (Kanipe, 2016; Kitsko, 2019; Stewart, 2009) is puzzling. None of the most recently published studies

\footnotetext{
${ }^{1}$ One possible source may be a 1991 survey of 1,000 pastors in the United States conducted by Fuller Theological Seminary, in which 50 percent are reported to have considered leaving ministry in the previous three months, but this too is anecdotal (Wind \& Rendle, 2001). Headington also references psychologist Richard Blackmon's (1985) doctoral dissertation from Fuller Theological Seminary, "The Hazards of the Ministry," but no data related to attrition is reported there, confirming that the 50 percent statistic derives from a different source.
} 
from the Alban Institute and Duke University (Hoge \& Wenger, 2005; Wind \& Rendle, 2001) report attrition rates anywhere near this level.

With recent studies failing to support such alarming attrition rates, why does the perception of a clergy crisis persist? One reason is that precise rates are difficult to determine, complicating the construction of a compelling counter-narrative (Chang, 2004). As we have noted, there is no coordinated research base; the data relies on individual studies emerging at irregular intervals from denominational bodies or individual researchers. Denominational record keeping varies in quality. Across studies, inconsistent definitions and metrics also cloud the picture. For the purposes of this study, we sought to define attrition as the phenomenon of people serving in full-time congregational ministry who have left congregational ministry before the anticipated age of retirement in order to pursue other types of work (either in religious ministry or other occupations). For a number of reasons, we found that the data does not always support such a clear definition. The actual experiences of clergy often exist along a spectrum that complicates a clear-cut definition of "leaving the ministry." For one thing, some leave parish ministry for a time and later return, while some transition to different roles either inside or outside of the church, which they understand as a fulfillment of their call to a more expansive definition of ministry (Boorstein, 2013; Deasy, 2018), and studies do not always make this distinction. Another complication is that it is difficult to distinguish clearly between "voluntary" and "involuntary" leavers, since that distinction often depends on how an individual perceives and articulates the circumstances surrounding his or her departure (Hoge \& Wenger, 2005). Finally, there is considerable overlap between the literature on clergy burnout and attrition (Adams et al., 2017), extending the range of sources from which valuable information on attrition can be gleaned. Because burnout can lead to attrition, many contributing factors are the same. But burnout does not necessarily lead to or precipitate attrition, so while the burnout literature can provide useful insight, it is not our primary focus here. 


\section{Attrition Among Protestant Clergy}

Turning to research that is grounded by solid empirical evidence, the most influential study to date of attrition among Protestant clergy continues to be the book Pastors in Transition: Why Clergy Leave Local Church Ministry by Hoge and Wenger. Published in 2005 as part of a multi-year research project on pastoral leadership conducted at Duke University Divinity School and with support from the Lilly Endowment, their original research has been an important framework for understanding clergy attrition for the past fifteen years. Alongside this work, a number of new sources have emerged to illuminate our understanding of Protestant clergy attrition. Most notably, Choi \& Blue (2011) conducted a retention study of United Methodist clergywomen; Randall (2013) reported on a comprehensive, longitudinal study of all clergy ordained in the Church of England in England and Wales beginning in 1994; the Evangelical Lutheran Church of America published a summary of personnel statistics (2016); and Gunsalus (2016) reported on the situation in the Wesleyan Church in North America. Gortner (2013) provided a useful and brief update on the most recent data collected directly from a handful of denominations in the United States, and the North American Mission Board of the Southern Baptist Convention and the Barna Group each released major reports on the situation among evangelicals in 2015 and 2017, respectively. Other sources have emerged to shed light on the process of transition for voluntary and involuntary leavers (Lamont, 2011; Tanner et al., 2012), and specific factors related to attrition (Fallon et al., 2013; Faucett et al., 2013; Royle et al., 2014; Spencer et al., 2012).

So how many clergy actually depart local church ministry each year? From 2010-2012 researchers from Boston University School of Theology conducted a study of all active and retired United Methodist Clergywomen that analyzed survey data from a total of 1,906 respondents, (the reported response rate was 18.6 percent; Choi \& Blue, 2011). The survey examined “clergywomen's reality in ministry" in detail, comparing the results with an earlier study from 1994 (see Wiborg \& Collier, 1999). This study revealed that about 17 percent of female clergy had temporarily left and then returned to local church ministry and that this was essentially unchanged from 1994. Only 1.4 percent of respondents had permanently surrendered their credentials, compared to 3.2 percent in 1994. Among women who had left 
temporarily or permanently, the most commonly cited reason for leaving was "to follow a call to another kind of ministry" (20 percent); "family responsibilities" (18 percent); and "lack of support from the hierarchical system" (15 percent). There were significant methodological challenges with this study. At 18.6 percent, the response rate was low, and because this study only included active and retired clergy, it likely missed a large portion of clergy who permanently surrendered their credentials and did not participate in the retirement program.

The Clergy into Action initiative of Virginia Theological Seminary contacted the research departments of the governing bodies of several protestant denominations in 2013. Compiling their responses, Gortner (2013) found that best estimates of attrition rates range from 1 percent in the United Methodist Church to 16 percent in the Nazarene Church in the first five years following ordination, a range that may in part be accounted for by differences in how clergy are supported between evangelical and mainline Protestant denominations.

In 2015, the North American Mission Board of the Southern Baptist Convention, in conjunction with Lifeway Research, surveyed 1,500 pastors (McConnell, 2015). They asked each pastor to report on who led their church 10 years ago, and, to their knowledge, where the previous pastor had gone after leaving the church. The study estimated that 10 percent of senior pastors in 2005 had left the pastorate ten years later for reasons other than death or retirement; of those who left, half were still in ministry positions (Cannon Green, 2015). The limitation with this study is that it relied on reports from the current pastor about where the pastor from 10 years ago had gone - 16 percent of current pastors did not know who the pastor was 10 years ago and 3 percent did not know where the former pastor was currently. This means the actual attrition rate could be higher. Methodological limitations aside, this study challenged the notion that evangelical pastors leave more frequently because of less hierarchical denominational structures and pastoral candidates having less experience working in ministry roles prior to an initial pastoral tenure (Gortner, 2013). 
In 2016, the Education and Clergy Development office of The Wesleyan Church in North America conducted a comprehensive review of district journals from the previous five years. Researchers found that of 483 ministers ordained in the North American General Conference of the Wesleyan Church from 2005-2008, 86 percent were still serving in parish ministry after five years; 6 percent had left in good standing (presumably including retirement), 4 percent had been removed, and 4 percent had left for unknown reasons, meaning that 8 percent of pastors had left over a five-year period (Gunsalus, 2016).

These rates, all collected within the past ten years, hover in a range similar to what has been shown in earlier research. A study of United Methodist Church ordinands (1998) used twenty years of data (1974-1994) to report on changes occurring in the rosters and in the careers of ministers during that time. Memming found that ten years after ordination 58.5 percent of clergy were still appointed to congregations (60.3 percent of them men, 47.5 percent of them women) and only 7 percent had left the denomination either voluntarily or due to termination.

Zikmund et al. (1998) surveyed almost 5,000 male and female clergy across fifteen denominations, with in-depth follow-up interviews with 248 respondents and found by age 45-50, 67 percent were still serving in local church ministry (although more men than women: 75 percent vs. 59 percent). Also in 1998, the Research Offices of the Presbyterian Church (U.S.A.) estimated that 11-13 percent of the 1990-92 graduating class was no longer in active ministry. ${ }^{2}$

So how many clergy permanently leave active ministry before retirement or death? Not that many. Because definitions and data quality vary, the estimates are imprecise, but best estimates suggest that annual attrition rates across Protestant denominations in the United States are generally around 1-2 percent, with occasional context-specific anomalies (cf. Ballis, 1999; Klaas \& Klass, 1999). The first five years of ministry are widely recognized as the most high-risk, but definitive data is still unavailable;

\footnotetext{
${ }^{2}$ The original study could not be located; the above summary cites (Hoge \& Wenger, 2005, p. 225)
} 
Gortner's estimate of 1-16 percent attrition within the first five years is the best approximation we found. There is little evidence that attrition rates are especially high during the first five years, especially when compared to professions like teaching, where early attrition is a much larger factor. Ingersoll et al. (2018) estimate that 44 percent of new teachers in public and private schools leave teaching within 5 years of entry.

\section{Attrition among Roman Catholic Priests}

For the sake of consistency, we initially planned to focus primarily on attrition among diocesan priests, as opposed to religious priests. This proved almost impossible since clear distinctions between diocesan and religious priests and the various roles that they fill are often not consistently maintained in the literature.

The unique experiences of those in consecrated life have been especially underrepresented in the literature (Bendyna \& Gautier, 2009; Kramarek \& Gaunt, 2017) and represent rich potential for further inquiry. For example, observing that 1,600 men and women left the consecrated life in 2019 due to "faith crises, community life crises, and affective crises," the Congregation for Institutes of Consecrated Life and Society of Apostolic Life, a department of the Vatican, has recently published a document addressing the phenomenon (Congregación para Institutos de Vida Consagrada y Sociedades de Vida Apostólica, 2020). Secretary José Rodríguez Carballo says the document comes in response to the recognition that consecrated life faces a crisis of fluid fidelity, underscoring the need to better understand "why and how it's come to this" (Díaz Vizzi, 2020; for demographics and data on the decline in religious life more generally see M. Gautier \& Do, 2020; Kramarek \& Gaunt, 2019).

The most recent large-scale sociological studies to produce original data on resigned priests occurred in the 1990s and early 2000s (Hoge, 2002; Schoenherr et al., 1993). More recent literature has relied heavily on this earlier research for projections of resignation rates or to inform smaller, qualitative studies, and we could find only two original studies to have emerged in the past ten years: Fichter (2015) studied ex-priests who have since become married Protestant ministers, and Pietkiewicz (2016) qualitatively explored the exit process of ten former priests in Poland. With few exceptions (Pietkiewicz, 
2016; Salvini, 2007; Schoenherr \& Vilariño, 2013), the literature is dominated by the situation among priests in the United States.

As with the situation among mainline Protestant denominations, precise numbers of priest resignations are unavailable since resignation data often fail to differentiate between losses due to retirement, death, and resignation (Pietkiewicz, 2016; Sullins, 2016). No consistent exit process exists for priests who choose to resign, with many former priests never requesting a formal dispensation (Hoge, 2002, p. 34). Estimates are further complicated by "frequently inconsistent use of the unit of analysis in reporting of the results within the same study. The literature...tends to focus on parish pastors (as opposed to all priests or priests in various ministries), priests in general (again, without consistently distinguishing between diocesan priests and religious priests), and members of religious institutes (without consistently distinguishing between men and women religious or between religious priests and religious brothers)" (Kramarek \& Gaunt, 2017, p. 2).

Estimates indicate that roughly 1-3 percent of new ordinands - those ordained within the past ten years - resign each year. Extrapolating from previous research, Kramarek \& Gaunt (2017) report that of an estimated 4,292 new religious and diocesan priests, 585 — or just under 14 percent —are at risk of resigning within ten years of their ordination or final profession (p. 2). Drawing on previous research, Hoge (2002, p. 2) reported that resignations of diocesan and religious ordinands within five years ranged from 4.3 percent to 9 percent between 1970 and 1994, steadily rising each decade with rates slightly higher among diocesan priests. Sullins (2016) arrived at comparable estimates, citing a global defection rate of roughly 10 percent within ten years and 15 percent by thirteen years. Across the literature, even the most recent estimates rely on data collected from studies that were conducted more than ten years ago.

In these studies, resigned priests tended to be younger than average (average resignation age was about 36) and had been four to five years younger at ordination than active priests (Greeley et al., 1972; Hoge, 2002). 32 percent of those who resigned within five years of ordination had first thought seriously about resignation prior to ordination (Hoge, 2002). Other demographic variants involving life prior to or 
during seminary were not found to be significantly predictive of resignation (Hoge, 2002). Again, despite the fact that the occupation structure of clergy differs greatly between the Catholic Church and Protestant denominations, it appears that similar numbers of clergy leave prematurely each year.

\section{Comparisons to Other Occupations}

Comparing pastors and priest attrition to other professions is difficult due both to the fact that pastoral ministry is a job with few analogues and reliable statistics on attrition in other occupations are difficult to find. Even when data from other occupations exist, it is hard to pin down why the differences in attrition exist. As Helen Rose Ebaugh (1988) has revealed in her work on "ex-es", attrition is related to primary factors like the intensity of attachment to the role. It is much harder for people to leave roles to where their degree of self-involvement is high. But intensity of commitment to a role is not necessarily the determinative factor. Workplace stress and burnout; pension and retirement benefits structure; debt load accrued during training; salary; the gender, age, and marital status of the workforce; the size and type of organizations where people work; the level of unionization; the availability of alternative careers - all exert a major impact on rates and timing of attrition. In addition, attrition is inherently difficult to measure - it requires longitudinal data that tracks people's careers over time. Rarely do data include information on why a person chose to leave a profession and they often miss temporary leavers- those who leave for a time (say to care for young children) but later return. This is related to the other source of confusion in studies of attrition. Not all studies make it clear what is being measured - the per-year incidence rate of clergy leaving a particular denomination or the prevalence of attrition among all those who have ever served as clergy. This distinction is important for clergy, who may leave congregational ministry at various points in their career to serve in denominational roles, but later return to the local church.

With these caveats aside, primary and secondary school teachers have been comprehensively studied. Among those who graduated from college in 1993, 10 years later, 30 percent of those who began in teaching had left the profession permanently (Ingersoll et al., 2018). The teaching profession appears to 
have a higher attrition rate in both the early years and late years. Early attrition is driven in large part because the majority of teachers are women and take time off to care for children, and later attrition by the fact that many pension plans allow teachers to retire earlier than age 65 (Harris \& Adams, 2007; Ingersoll et al., 2018). Teachers have similar rates of attrition as police officers (28 percent of 1993 graduates left policing by 2003), modestly higher rates than nurses and lawyers (19 percent), engineers (16 percent) and pharmacists (14 percent), but much lower rates than childcare workers (45 percent) and secretaries (79 percent) (Ingersoll et al., 2018). Emergency medicine physicians have also been studied extensively. One of the most comprehensive studies of this group reports that within 2 years of certification, 6.5 percent had left the profession, after 20 years, about 18 percent had left emergency medicine (Ginde et al., 2010). Within these professions, clergy appear similar to nurses, lawyers, engineers and pharmacists.

\section{Why Pastors Leave}

\section{Protestant Clergy}

Compared to prevalence rates of attrition there is more research focused on identifying and mitigating the factors that lead to attrition. As the most comprehensive study of this topic, Hoge and Wenger's book, Pastors in Transition, has had a major influence on the literature surrounding pastoral attrition. For their book, Hoge and Wenger surveyed 963 former pastors from five mainline denominations (the Presbyterian Church (U.S.A.), Evangelical Lutheran Church of America, United Methodist Church, Lutheran Church (Missouri Synod), and Assemblies of God) and conducted 90 followup phone interviews. They point out that it is a mistake to assume that pastors leave because something has gone wrong. Instead, there is often a combination of push and pull factors that influence the decision to leave or stay in pastoral ministry. They estimated that among their study participants who left ministry, 40-50 percent were voluntary leavers who experienced one or more negative factors that ultimately tipped the scales towards leaving. An additional 30-40 percent were involuntary leavers. These pastors would have liked to stay in congregational ministry but were pushed out due to factors including conflict 
within congregations, tensions with denominational officials, or sexual misconduct or divorce. Finally, 15-20 percent were voluntary leavers who were ultimately pulled in a different direction, usually either to pursue another form of ministry outside of the church or to attend to family needs. Importantly, pastors rarely left due to personal problems: "institutional and interpersonal problems were more significant factors than [personal problems such as] loss of faith, health problems, or financial difficulties" (Hoge \& Wenger, 2005, p. 198).

In another large study, a fourteen-year longitudinal study of all clergy ordained in the Church of England and the Church of Wales examined whether it was possible to distinguish potential leavers by evaluating stress and emotional exhaustion in routine psychological assessments (Randall, 2013). Among the 7 percent who had left the ministry after seven years, the most predictive factors were age, a more liberal theological orientation, and scoring higher on measures of introversion and emotional exhaustion. Randall concluded that "the incompatibility between personal preferences and public expectations of their role as parish clergy may have led to frustration, stress, and a sense of failure" (2013, p. 187). In other words, those who left parish ministry had experienced greater degrees of occupational mismatch than those who remained in active ministry.

In 2002, the $212^{\text {th }}$ General Assembly of the Presbyterian Church (U.S.A.) appointed the Advocacy Committee for Women's Concerns to explore “why women leave parish ministry and why lower numbers of women serve congregations" (Advocacy Committee for Women's Concerns, 2002, p. 2). They fielded a survey of 1,404 active or retired clergywomen. And while the results of the survey did not reflect a decision to leave the ministry altogether, 63 percent of respondents reported having left a congregation for reasons other than retirement. While the individual reasons were many, the primary factors motivating these transitions fell into a few categories: 52 percent involved some kind of difficulty within the position, ranging from interpersonal conflict to discrimination or mismatch; 52 percent had to do with personal reasons, including family needs, life changes, or illness; 31 percent were due to a normal course of events such as receiving another call; and only 11 percent were due to leaving for an alternative 
ministry or secular job (percentages do not add up to 100 as people could select more than one reason). In another study of the primary factors for leaving reported among a sample of Presbyterian pastors no longer in ministry were feeling a "sense of completion of call," experiencing some sort of conflict, either within the congregation or between the pastor and denominational hierarchy, seeking more time for family (a factor that only women reported), or because of personal health reasons (a factor primarily reported by men, Presbyterian Church (U.S.A.) Research Services, 1999). ${ }^{3}$

In another large study, Zikmund et al. (1998) found that among leavers, the main motivating factors boiled down to a lack of support, either personal or structural: respondents had not consistently been part of a clergy support group; those in difficult situations were not hopeful that they would be able to get a better position, and thus thought that leaving the ministry altogether was their only alternative; and they did not feel recognized and appreciated by denominational leadership. Reanalyzing the same data with greater scrutiny of the determinants of pastors' decisions to leave the ministry, Lummis (1996) agreed: a lack of professional support, at either the personal of institutional level, was the main reason for leaving. ${ }^{4}$

Several studies have paid particular attention to the experiences of evangelical pastors. Spencer et al. (2012) surveyed 285 evangelical clergy to explore risk factors of forced or unforced resignations and found two predictive areas of concern: "vision conflict," or a sense of disparity between a pastor's expectations and actual experience of ministry; and "compassion fatigue," or the depletion of a pastor's spiritual and emotional reserves to the point of exhaustion. In both domains, the most significant factors in contributing to vision conflict and compassion fatigue were lack of an effective support team and/or serving in a congregation with declining attendance (Spencer et al., 2012, p. 95). In Lifeway's 2015 study

\footnotetext{
${ }^{3}$ The original report could not be located; the above is summarized from Hoge \& Wenger (Hoge \& Wenger, 2005, pp. 224-225).

${ }^{4}$ The survey data was collected 1993-1994, and Lummis' independent analysis was published in 1996, but the full report by Zikmund et al. did not appear in print until 1998.
} 
where the current pastor was asked to report the reason the pastor from 10 years ago left the church, 53 percent cited a change in calling, poor fit with a church, or lack of preparation for the job as the most significant factors in decisions to exit, 26 percent reported conflict within the church. 17 percent named family issues followed by 13 percent who reported moral or ethical issues, 10 percent burnout, 8 percent personal finances, and 5 percent illness (McConnell, 2015). In 2013, a study of 25 ex-pastors and 25 lay leaders from the North Carolina Conference of the International Pentecostal Holiness Church found that both pastors ( 84 percent) and lay leaders (92 percent) overwhelmingly agreed that the primary reason for early pastoral departures was irresolvable conflict that had occurred between the pastors and congregational leadership (Hughes, 2013). Similarly, Scott (2018) conducted a small study of pastors and laity in rural Alabama and found that ministry burnout and failure (defined as leaving the pastorate) were most often the result of conflict caused by differences in expectations between a pastor and congregation, either related to performance or compensation.

Turning to earlier studies of why pastors leave, Jud et al. (1970) surveyed 241 former United Church of Christ pastors and conducted follow-up interviews with 131. Compared to a control group of current pastors, the ex-pastors reported having had more frequent church moves and unstable ministry positions throughout their tenure, as well as more marital crises and family problems. Mills (1969) studied sixty male Presbyterian ministers who had recently gone through career changes. ${ }^{5}$ Of these sixty, only a small group had left the ministry altogether. Compared to those who had transitioned to another pastorate, an executive church position, or had left to pursue graduate work, the group leaving parish ministry had usually served in smaller churches, and they reported finding less satisfaction in their work, less support and more pressure to compromise from their congregations and denominational oversight, and higher rates of marital crises.

\footnotetext{
${ }^{5}$ Although it is cited throughout the literature, Mills' original study could not be located. The above is summarized from Hoge and Wenger (2005, p. 221).
} 
If any conclusions can be drawn from the literature about primary factors driving premature clergy exits, it is that they are many and multiple. In response to almost 40 percent of Seventh-Day Adventist pastors in New Zealand and Australia exiting the ministry from 1980-1988, Ballis (1999) conducted in-depth interviews with 43 ex-pastors to examine the unique crises that precipitated this particular event. Ballis concluded that "exit is presented not as an orderly progression of predictable steps, but as the culmination of a host of painful experiences, and contradictory thoughts and emotions" (1999, p. 8). But in spite of the turmoil that often surrounds leaving pastoral ministry, two broad themes emerge from the literature. First, many ex-pastors cite some form of mismatch, in which a pastor finds that their expectations, training, or gifts are misaligned with the occupational responsibilities that they encounter. This can occur at a number of different levels, including personality fit and aptitude for a people-oriented, emotionally demanding job; unforeseen contextual factors or placement in a ministry environment mismatched to a person's background and preferences; or feeling insufficiently prepared in either expectations or skills for the demands of the job (especially a lack of managerial or administrative skills). A second broad theme is related to interpersonal conflict, either within the congregation (more common in the experiences of evangelical clergy) or with denominational leaders and authority figures (primarily in mainline Protestant denominations). The isolation and lack of support that pastors of all denominations frequently report can also be understood to fall within this broad theme; when pastors feel unsupported, either by fellow clergy or by their supervisors and authority figures, experiences of conflict are intensified.

There are two demographic factors influencing exits from ministry that are worth noting. Wiborg and Collier's (1999) early study of United Methodist clergy women found that women left the parish ministry at a 10 percent higher rate than male clergy, usually because they transition to non-parish-based ministry (28 percent) or had experienced significant challenges in getting the support they needed from denominational leadership (28 percent). Choi and Blue's (2011) follow-up study produced similar results: overwhelmingly, the number one reason women resigned from their posts was lack of denominational 
support (cited by 35 percent of white women and 44 percent of minority women), followed by family responsibilities (13 percent) and a sense of being unable to maintain integrity within the hierarchical system (13 percent). Hoge and Wenger found that men and women left at about the same rate, except in the Presbyterian Church, where women were more likely to resign (2005).

Second, it has been widely assumed that early-career pastors are at the greatest risk of experiencing challenges significant enough to lead to premature resignation (Kitsko, 2019). The real challenges of transitioning into ministry have been a particular focus of theological education in recent years (cf. Gortner, 2013; Wind \& Wood, 2001). There are some indications that younger clergy are more prone to burnout (Randall, 2013), as well as those serving in small or struggling congregations, where new ordinands are more likely to be placed (Mills, 1969; The Barna Group, 2017), but the literature simply does not support claims that early-career pastors resign at significantly higher rates. The majority of studies do not control clearly enough for age or length of tenure for specific conclusions to be drawn; those that do found no significant differences. In Hoge and Wenger's sample, the average age of departure from parish ministry was 44 , and average age when beginning local church ministry was 29 ; this produces an average ministry tenure of fifteen years.

Some notable factors have consistently ranked fairly low in considerations of ministry departures. Hoge and Wenger found between 3-12 percent of pastors cited financial considerations, with the highest percentage among Assemblies of God clergy. While pastors sometimes cited doctrinal disagreements, a lack of confidence in gifts or calling, or disillusionment with the church or organizational structures, none mentioned a loss of faith. Similarly, no more than 2-3 percent of UMC clergywomen cited financial reasons in their decision to leave, ranking much lower than issues related to a lack of support (31 percent), mismatch (27 percent), or family responsibilities (18 percent); none specifically discussed doubting their faith or calling (Choi \& Blue, 2011). Among evangelicals, 8 percent of leavers in the 2015 Lifeway study cited financial reasons, compared to a combined 53 percent due to factors related to mismatch or 26 percent related to conflict. However, more than half of current pastors in the study agreed or strongly 
agreed that they were often concerned about their family's financial situation (McConnell, 2015). While further research is needed to understand which pastors are concerned about finances and to what degree, it seems relatively clear that money is not a primary driver of either burnout or attrition. ${ }^{6}$

\section{Roman Catholic Clergy}

As with research on Protestant clergy, the focus on priest resignations has tended to prioritize an understanding of motivating factors over determining precise rates of resignation. For decades, studies of Roman Catholic clergy have consistently revealed what Hoge most clearly articulated in 2002: "We found that most resignees had two levels of motivation: one, a feeling of loneliness or being unappreciated; two, an additional situation or event that precipitated a crisis of commitment. Both are needed to bring about a resignation; either level taken alone is not enough" (DellaCava, 1975; Greeley, 2004; Hoge, 2002, p. 63). The first motivator, that of feeling lonely or unappreciated, is most often tied to the rejection of celibacy and/or a desire to marry, rather than a lack of support from institutional church structures or difficulty in specific ministry contexts. Identifying the principal factors in priest resignation as youthfulness, a desire to marry, and loneliness, Greeley and Schoenherr described how they are related: "The desire to marry is explained almost completely by the individual's perception of loneliness as a problem and by his younger age” (Schoenherr \& Greeley, 1971). In a survey of administrators of men's religious communities, 69 percent of administrators mentioned preference for marriage as a primary reason for priest resignations in preceding years; 68 percent cited problems with celibacy, 63 percent lack of personal fulfillment, and 61 percent dissatisfaction with community life (Verdieck et al., 1988). Fifteen years later, 42 percent of resigned priests cited the desire to marry or to pursue an intimate heterosexual relationship as their main motivation for resignation, with 26 percent finding celibacy to be a problem (Hoge, 2002). While decades

\footnotetext{
${ }^{6}$ The exceptions to pastors' relative ambivalence about economic considerations were the Lutheran clergy interviewed by Klaas and Klaas in the late 1990s. While economic considerations were not among the top frustrations cited by pastors, they were nonetheless significant; this seems to be related to the unique denominational structures in place in the Lutheran Church-Missouri Synod during that time, and not generalizable across denominations.
} 
of research have shown that the desire to marry is the primary motivating factor in priest resignations (Pietkiewicz, 2016; Schoenherr \& Vilariño, 2013; Schoenherr \& Young, 1990; Verdieck et al., 1988). Richard Schoenherr has been the most vocal in his critique of the effects of mandatory celibacy on the priesthood, concluding that "the celibacy requirement is keeping young men who want to from entering the priesthood and driving out many of those who do get ordained" (1995, p. 12, 2004).

Hoge's research describes a typology of priests who leave due to dissatisfaction with celibacy. Type 1 priests (roughly 20-30 percent of all resigned priests) felt lonely or unappreciated, and then fell in love with a woman; type 2 priests (20-30 percent) felt lonely or unappreciated, and decided they could no longer continue as a celibate although no specific woman was yet involved; type 3 priests (30-40 percent) felt lonely or unappreciated, and then became disillusioned by experiences with fellow priests or Church hierarchy; and type 4 priests (5-15 percent) felt lonely or unappreciated and chose to pursue an open, long-term relationship with a man (Hoge, 2002, pp. 63-64). But, while the requirement to remain celibate is an important factor in the decision to leave the priesthood, intimate relationships - or a desire to pursue them - are not enough to drive a priest to resignation; cofactors contributing to dissatisfaction or disillusionment are always present (DellaCava, 1975; Greeley, 2004; Hickson et al., 1995; Pietkiewicz, 2016).

What are these cofactors? While much less significant than factors related to celibacy or marriage, resigned priests also differ from active priests in their experiences in the priesthood, sources of satisfaction, perception of problems priests face today, and attitudes about the priesthood and Church. In Hoge's study, 16 percent cited "dissatisfaction with Church administration or trends," half as many resigned priests found their first assignment after ordination "very helpful" in transitioning into ministry, and almost 20 percent fewer resigned priests felt that they had enough freedom and authority to make decisions in carrying out ministry (Hoge, 2002). Only 18 percent of resigned priests felt "very satisfied" with their living situation in their first assignment, compared to 49 percent of active diocesan and 41 percent of religious priests. Resigned priests also experienced more tension surrounding issues of priestly 
identity (about 10 percentage points higher than active priests), the exercise of heavy-handed authority in the Church (18-31 points higher), and their relationship with their bishop or superior (about 30 points higher). These responses were comparable to Greeley's findings in the 1970s, in which the main two reasons for resignation were the desire to marry and a rejection of authoritative institutional church structures (Greeley et al., 1972). Hoge characterized the latter slightly differently as "institutional criticism," meaning that the resignees he studied "seldom espoused serious institutional reforms" in their criticism, but the results of the studies share a clear resonance (2002, p. 102).

In spite of this, all cofactors have consistently been found to be less persistent, or to rank much lower than problems with celibacy or a desire to marry, suggesting that the decision to leave is not primarily a decision to "leave the ministry" but a rejection of celibacy as a requirement of ordained ministry. In fact, 64 percent of resignees say that if priests could be married, they would be interested in becoming an active married priest (Hoge, 2002, p. 33). According to Vatican records, of the 69,063 men who left the priesthood from 1964-2004, 11,213 (16 percent) have subsequently been returned to priestly service, including some who married and were widowed (Sullins, 2016). Furthermore, many resigned priests pursue other avenues for active or ordained ministry after resignation and marriage (Hoge, 2002). In a survey of 414 ex-priest clergymen serving in ordained ministry in one of the five mainline Protestant denominations (Episcopal, Lutheran, Methodist, Presbyterian, UCC), Fichter (2015) reported that 59 percent said they resigned from the priesthood because they wanted to marry and became Protestant so they could resume Christian ministry. Related to this is the often-overlooked phenomenon of married priests: between 1980 and 2016, roughly 125 former (married) Anglican or Episcopal priests in the United States became Catholic and were approved for ministry under the Pastoral Provision. Sullins reports that these priests generally cite reasons of authority or doctrine behind their decision to become Catholic, and that retention among this group is high: "Since 1981 only two married priests have resigned, both after five years" (2016, p. 12). 
Three smaller studies, emerging at 20-year intervals, have examined the process of transitioning out of the priesthood in greater depth. DellaCava (1975) conducted 35 open-ended interviews with expriests, exploring the conditions in which individuals become able to leave such a high-commitment status as priesthood. The process of leaving is much more complex than simply changing jobs, since religious life is "supported by heavy emotional investment on the part of the individual and has a central place in one's identity structure" (DellaCava, 1975, p. 41). Mere consideration of resignation "generates severe cross-pressures," and the decision is usually carefully weighed for years before the process is complete. Leaving the priesthood is, in essence, a process of resocialization, so that two conditions are necessary for leaving to occur: the formation of new primary relationships which provide support and begin to establish a role-identity outside that of priest, and the construction of "legitimations" for these new relationships which allow the priest to reinterpret his identity in a way that is consistent with his decision to leave. Although many issues may create role conflict for the priest, DellaCava concludes that this may be why celibacy tends to be the most powerful factor: the source of both role-conflict and resocialization is the same.

Surveying the historical and personal factors leading to priest resignation that have been discussed above, Hickson et al. (1995) “described the conflicts and challenges that arise when priests resign" in order to propose a group counseling approach to support transition into the laity. These challenges included experiences of withdrawal, personal anguish akin to a "dark night of the soul," an experiential void, and "prolonged periods of skepticism" and self-doubt. Some priests took a leave of absence for a year or more to wrestle with the decision. Some turned to family members or colleagues, which usually produced more conflict and turmoil. In short, Hickson characterized the process of transition as painful and isolating: "A priest's decision to exit the ministry caps a long process and soul searching...Because one's fellow priests may feel threatened by a priests' decision and because family members may believe he is suffering from emotional disturbance, the exiting priest can feel guilt ridden, isolated, and confused" (1995). More recently, Pietkiewicz (2016) has systematically charted the stages of 
this process of turmoil and transition by examining the experiences of ten former priests in Poland. He describes the process as having three stages of progression. In the first stage, "living a dilemma," participants experienced inner conflict between their private needs and aspirations, and the expectations about their role, leading to contemplation of an alternate path and associated feelings of dissatisfaction with their current situation, shame or guilt about their inner conflict, and anxiety about the potential of incurring social stigmas, disappointing others, and the spiritual and economic consequences of leaving the priesthood. In stage two, "attempts to resolve a conflict," participants reported trying to cope with their inner conflict in a number of ways, including ignoring it, taking a leave of absence, and seeking social and/or professional help. When none of these proved successful, the final stage of "taking a jump" was characterized by taking concrete action toward their future life, including deeper involvement in the relationships that had played a role in the decision to leave, resolving some of the ambiguities surrounding economic considerations, and telling others. In all of this, Pietkiewicz has provided one of the most concrete accounts of the complexity of the process of transition out of the priesthood.

\section{Summary}

While there are significant structural differences that affect both rates and reasons for attrition among Protestant and Catholic clergy, some resonance emerges in the literature. First, in both areas, more consistent and precise data on rates of resignation are needed. The available evidence suggests clergy are "not quitting in droves" (Dance, 2019) but the significance of occasional spikes in resignations is difficult to understand without a more detailed record with which to compare it. Similarly, countering popular perceptions of a clergy crisis is difficult in the absence of more thorough, consistent, and recent data on departures. Higher quality evidence on attrition rates would significantly strengthen recent studies showing that priests and pastors are generally satisfied with their work and are some of the happiest professionals overall (Adams et al., 2017; Smith, 2007). Second, for both Protestant and Catholic clergy, the decision to leave ministry involves a combination of both push and pull factors. Studies focused on Protestants surfaced indications of mismatch in their ministry situation or conflict with parishioners or denominational structures; studies of departing Catholic priests often revealed some degree of 
disillusionment or dissatisfaction with authority structures in the Church, along with a rejection of mandatory celibacy and desire to marry. Third, financial considerations or a loss of personal faith are fairly insignificant to both Protestants and Catholics in influencing a decision to exit ministry. This is not to say that these issues are irrelevant; many clergy report moderate financial concerns and various kinds of disillusionment with the church, its theology, or its people. But the literature shows that these are rarely the primary drivers in decisions to leave the ministry.

\section{Conclusions}

In recent years, the literature on clergy attrition and retention has seen a significant shift away from the narrow question of why priests and pastors leave parish ministry and toward a broader emphasis on understanding and cultivating wellbeing in all aspects of the pastoral profession. While the literature on the reasons clergy leaves is fairly robust, it is hampered by a basic lack of data about actual rates of attrition. On one hand, the assumption guiding Hoge and Wenger's research fifteen years ago remains implicit throughout the literature, which is that the actual numbers are not particularly significant since "the number leaving has always been too high." On the other hand, attrition may not actually be that much of a problem - some turnover is a natural part of any occupation and studies have shown that pastors do not leave the ministry in extraordinarily high numbers. Nevertheless, conclusions about both the incidence and prevalence of attrition among pastors serving local churches have largely been produced by piecing together data from only a handful of studies, conducted at infrequent intervals. Denominational record-keeping is still uneven, and where it does exist the numbers are imprecise. Regardless of whether the clergy attrition rate is too high or not, the question that must be addressed is whether the existing data on attrition and its factors is sufficient to guide the efforts of seminaries and denominations in preparing pastors to navigate and thrive in a complex and changing ministry landscape. 


\section{References}

Adams, C. J., Hough, H., Proeschold-Bell, R. J., Yao, J., \& Kolkin, M. (2017). Clergy Burnout: A Comparison Study with Other Helping Professions. Pastoral Psychology, 66(2), 147-175. https://doi.org/10/gfgqvb

Advocacy Committee for Women's Concerns. (2002). Clergywomen's Experiences in Ministry: Realities and Challenges (Internal Report to the General Assembly) (p. 24). Presbyterian Church (U.S.A.). https://www.pcusa.org/site_media/media/uploads/_resolutions/clergywomenexp03.pdf

Ballis, P. H. (1999). Leaving the Adventist Ministry: A Study of the Process of Exiting. Greenwood Publishing Group.

Bendyna, M. E., \& Gautier, M. L. (2009). Recent vocations to religious life: A report for the National Religious Vocation Conference. Washington, DC: Center for Applied Research in the Apostolate, 28.

Blackmon, R. A. (1985). The hazards of the ministry (Doctoral dissertation, Fuller Theological Seminary, School of Psychology, 1985). Dissertation Abstracts International, 46, 634B.

Boorstein, M. (2013, May 17). Seminary graduates not always ministering from the pulpit. Washington Post. https://www.washingtonpost.com/local/seminary-graduates-not-always-ministering-fromthe-pulpit/2013/05/17/d50b17ea-bd71-11e2-9b09-1638acc3942e_story.html

Cannon Green, L. (2015, September 1). Despite Stresses, Few Pastors Give Up on Ministry. LifeWay Research. https://lifewayresearch.com/2015/09/01/despite-stresses-few-pastors-give-up-onministry/

Chang, P. (2004). Assessing the clergy supply in the 21st century. Duke Divinity School.

Choi, H. A., \& Blue, J. (2011). United Methodist Clergywomen Retention Study II in the U.S. Context. Anna Howard Shaw Center, Boston University School of Theology. https://www.bu.edu/shaw/publications/united-methodist-clergywomen-retention-study-ii2/introduction-2/ 
Congregación para Institutos de Vida Consagrada y Sociedades de Vida Apostólica. (2020). El don de la fidelidad. La alegría de la perseverancia. http://www.publicacionesclaretianas.com/node/1423

Dance, M. (2019, July 10). Pastors Are Not Quitting In Droves. https://factsandtrends.net/2019/07/10/pastors-are-not-quitting-in-droves-2/

Deasy, J. A. (2018). Where are graduates serving? New insights from the Educational Models Alums Workforce Survey. The Association of Theological Schools, The Commissioning on Accrediting, Colloquy Online, 4.

DellaCava, F. A. (1975). Becoming an Ex-Priest: The Process of Leaving a High Commitment Status. Sociological Inquiry, 45(4), 41-49. https://doi.org/10.1111/j.1475-682X.1975.tb00348.x

Díaz Vizzi, D. (2020). Vatican publishes book on persevering in and abandoning religious life. https://www.romereports.com/2020/08/07/vatican-publishes-book-on-persevering-in-andabandoning-religious-life

Dirmann, T. (1999). Pastoral Pressures Test Faith. Los Angeles Times, 29. https://www.latimes.com/archives/la-xpm-1999-jan-29-me-2802-story.html

Ebaugh, H. R. (1988). Becoming an Ex: The Process of Role Exit. University of Chicago Press.

Evangelical Lutheran Church in America. (2016). Number of Clergy Retiring per year from 1988 to 2012 in the ELCA. http://download.elca.org/ELCA\%20Resource\%20Repository/Clergy_Retirements.pdf

Fallon, B., Rice, S., \& Howie, J. W. (2013). Factors that Precipitate and Mitigate Crises in Ministry. Pastoral Psychology, 62(1), 27-40. https://doi.org/10.1007/s11089-012-0486-4

Faucett, J. M., Corwyn, R. F., \& Poling, T. H. (2013). Clergy Role Stress: Interactive Effects of Role Ambiguity and Role Conflict on Intrinsic Job Satisfaction. Pastoral Psychology, 62(3), 291-304. https://doi.org/10.1007/s11089-012-0490-8

Fichter, S. J. (2015). From Celibate Catholic Priest to Married Protestant Minister: Shepherding in Greener Pastures. Lexington Books. 
Gautier, M., \& Do, T. (2020). Recent Vocations to Religious Life: A Report for the National Religious Vocation Conference (p. 157). Center for Applied Research on the Apostolate. https://nrvc.net/publication/download/9180/2020-nrvc-study-on-recent-vocations-final-march2020.pdf?view=true

Gautier, M. L., Perl, P. M., \& Fichter, S. J. (2012). Same Call, Different Men: The Evolution of the Priesthood since Vatican II. Liturgical Press.

Ginde, A. A., Sullivan, A. F., \& Camargo, C. A. (2010). Attrition From Emergency Medicine Clinical Practice in the United States. Annals of Emergency Medicine, 56(2), 166-171. https://doi.org/10.1016/j.annemergmed.2009.11.002

Gortner, D. (2013). How Many Quit? Estimating the Clergy Attrition Rate. Into Action - From Seminary into Ministry. http://into-action.net/research/many-quit-estimating-clergy-attrition-rate/

Greeley, A. M. (2004). Priests: A Calling in Crisis. University of Chicago Press.

Greeley, A. M., National Opinion Research Center, United States Catholic Conference, Catholic Church, National Conference of Catholic Bishops, \& Bishops' Committee on Priestly Life and Ministry. (1972). The Catholic priest in the United States. Publications Office, United States Catholic Conference.

Gunsalus, R. (2016, February 25). Shocking News about Wesleyan Pastor Washout: Wesleyan Clergy Retention Study. The Wesleyan Church. https://www.wesleyan.org/shocking-news-aboutwesleyan-pastor-washout-wesleyan-clergy-retention-study

Harris, D. N., \& Adams, S. J. (2007). Understanding the level and causes of teacher turnover: A comparison with other professions. Economics of Education Review, 26(3), 325-337. https://doi.org/10.1016/j.econedurev.2005.09.007

Headington, G. L. (1998). A guide to recovery for fallen pastors: The journey back from sexual misconduct. [Doctor of Ministry Dissertation]. Fuller Theological Seminary. 
Hickson, J. H., Gudz, G., \& Hornbuckle, D. R. (1995). Group Work With Catholic Priests Who Have Exited the Clerical World. Counseling and Values, 40(1), 32-44. https://doi.org/10.1002/j.2161007X.1995.tb00385.x

Hoge, D. R. (2002). The First Five Years of the Priesthood: A Study of Newly Ordained Catholic Priests. Liturgical Press.

Hoge, D. R., \& Wenger, J. E. (2005). Pastors in Transition: Why Clergy Leave Local Church Ministry. Wm. B. Eerdmans.

Hughes, W. E. (2013). Assessing the Causes of Short-term Pastorates in the North Carolina Conference of the International Pentecostal Holiness Church [PhD Thesis]. Oral Roberts University.

Ingersoll, R. M., Merrill, E., Stuckey, D., \& Collins, G. (2018). Seven Trends: The Transformation of the Teaching Force-Updated October 2018 (p. 28). Consortium for Policy Research in Education.

Jud, G. J. (1970). Ex-pastors: Why Men Leave the Parish Ministry. Pilgrim Press.

Kanipe, R. W. (2016). Clergy stress, complex trauma and Sabbath practice: A study on Sabbath practice as healing process for clergy serving in stressful appointments.

Kitsko, M. D. (2019). Early Career Attrition of Seminary Graduates: Effects of Perceived Fit, Early Childhood Experiences, Financial Debt, and Mentoring [Ph.D., Michigan State University]. http://search.proquest.com/docview/2284870909/abstract/A8F6598CC08B41E8PQ/1

Klaas, A., \& Klass, C. (1999). Clergy Shortage Study. The Lutheran Church - Missouri Synod. http://www.ctsfw.net/media/pdfs/KlaasClergyShortageStudy.pdf

Kramarek, M. J., \& Gaunt, T. P. (2017). The Needs of Recently Ordained Priests and Professed Religious in Their First Ten Years of Ministry. Center for Applied Research in the Apostolate. https://1mkaop1ht16m2its812mogf3-wpengine.netdna-ssl.com/wpcontent/uploads/2019/09/The_Needs_of_Recently_Ordained_Priests_and_Professes_Religious_i n_Their_First_Ten_Years_of_Ministry.pdf

Kramarek, M. J., \& Gaunt, T. P. (2019). Supporting Training for Women and Men in Religious Life in the Ten Years Following their Final Profession (p. 8). Center for Applied Research in the Apostolate. 
Lamont, R. (2011). Leaping the Vicarage Wall: Leaving Parish Ministry. Bloomsbury Publishing.

Lummis, A. (1996). Why Men and Women Leave the Ministry: Hypotheses from Research on Clergy and from Role Exiters of Other Statuses. In S. Farrell (Ed.), The Power of Gender in Religion. McGraw-Hill Primis Custom Publishing.

McConnell, S. (2015). Pastor Protection Research Study: Survey of 734 Pastors who Left the Pastorate before age 65. LifeWay Research. http://lifewayresearch.com/wpcontent/uploads/2016/01/Pastor-Protection-Former-Pastor-Survey-Report.pdf

Meek, K. R., Meek, M. R., Brower, C. M., Burnett, T. D., McRay, B. W., Ramey, M. L., Swanson, D. W., \& Villa, D. D. (2003). Maintaining Personal Resiliency: Lessons Learned from Evangelical Protestant Clergy. Journal of Psychology and Theology, 31(4), 339-347.

Memming, R. (1998). United Methodist Ordained Ministry in Transition. In W. B. Lawrence, D. M. Campbell, \& R. E. Richey (Eds.), The People(s) Called Methodist: Forms and Reforms of Their Life (pp. 129-150). Abingdon Press.

Mills, E. W. (1969). Career change in the Protestant ministry. Ministry Studies, 3(1), 5-21.

Ministering to Ministers Foundation, Inc. (2016). Clergy Losses Are Massive. https://ministeringtoministers.org/clergy-losses-are-massive/

Pietkiewicz, I. J. (2016). Reaching a decision to change vocation: A qualitative study of former priests' experiences. International Journal for Educational and Vocational Guidance; Dordrecht, 16(3), 379-404. http://dx.doi.org/10.1007/s10775-015-9318-2

Presbyterian Church (U.S.A.) Research Services. (1999). Ministers Ordained in the 1990s: A Look at Clergy Who Have Left the Ministry. Presbyterian Church (U.S.A.).

Randall, K. J. (2013). Examining Thoughts About Leaving the Ministry Among Anglican Clergy in England and Wales. Practical Theology, 6(2), 178-189. https://doi.org/10.1179/1756073X13Z.0000000005

Rediger, G. L. (1997). Clergy Killers: Guidance for Pastors and Congregations Under Attack. Westminster John Knox Press. 
Royle, M. H., Norton, J., \& Larkin, T. (2014). Stress and Psychological Type Among Clergy in the Reformed Church in America. Review of Religious Research, 56(2), 337-338. https://doi.org/10.1007/s13644-014-0152-7

Salvini, G. (2007). Priests Who "Desert”, Priests Who “Come Back.” La Civiltà Cattolica, 3(3764). https://www.catholicculture.org/culture/library/view.cfm?recnum=7803

Schoenherr, R. A. (1995). Numbers don’t lie. Commonweal, 122(7), 11.

Schoenherr, R. A. (2004). Goodbye Father: The Celibate Male Priesthood and the Future of the Catholic Church. Oxford University Press, USA.

Schoenherr, R. A., \& Greeley, A. M. (1971). A Causal Model to Explain Resignations in the American Catholic Priesthood. National Opinion Research Center, University of Chicago.

Schoenherr, R. A., Schoenherr, P. of S. R. A., Young, L. A., \& Cheng, T.-Y. (1993). Full Pews and Empty Altars: Demographics of the Priest Shortage in United States Catholic Dioceses. University of Wisconsin Press.

Schoenherr, R. A., \& Vilariño, J. P. (2013). Organizational role commitment in the Catholic Church in Spain and the USA. In C. J. Lammers \& D. Hickson (Eds.), Organizations Alike and Unlike: International and Inter-Institutional Studies in the Sociology of Organizations. Routledge.

Schoenherr, R. A., \& Young, L. A. (1990). Quitting the Clergy: Resignations in the Roman Catholic Priesthood. Journal for the Scientific Study of Religion, 29(4), 463-481. JSTOR. https://doi.org/10.2307/1387312

Scott, T. L. (2018). Identifying the Perils of the Pastorate of the Missionary Baptist Church in the Rural Areas of the Southeast District Association of Butler and Crenshaw Counties, Alabama [D.Min., South University]. http://search.proquest.com/docview/2226238497/abstract/FE43C29BADDC482DPQ/1

Smith, T. W. (2007). Job Satisfaction in the United States (p. 9). NORC/University of Chicago. 
Spencer, J. L., Winston, B. E., \& Bocarnea, M. C. (2012). Predicting the Level of Pastors' Risk of Termination/Exit from the Church. Pastoral Psychology, 61(1), 85-98. https://doi.org/10.1007/s11089-011-0410-3

Stewart, K. (2009). Keeping Your Pastor: An Emerging Challenge. Journal for the Liberal Arts and Sciences, 13(3), 112-.

Sullins, D. P. (2016). Keeping the Vow: The Untold Story of Married Catholic Priests. Oxford University Press.

Tanner, M. N., Zvonkovic, A. M., \& Adams, C. (2012). Forced Termination of American Clergy: Its Effects and Connection to Negative Well-Being. Review of Religious Research, 54(1), 1-17. https://doi.org/10.1007/s13644-011-0041-2

The Barna Group. (2017). The State of Pastors. Barna Group.

Transition into Ministry. (2021). Transition into Ministry Programs May Reduce Clergy Attrition Rate. Into Action - From Seminary into Ministry. http://into-action.net/research/tim-programs-mayhelp-new-clergy-stay-ministry/

Verdieck, M. J., Shields, J. J., \& Hoge, R. (1988). Role Commitment Processes Revisited: American Catholic Priests 1970 and 1985. Journal for the Scientific Study of Religion, 27(4), 524-535. JSTOR. https://doi.org/10.2307/1386947

Wiborg, M. S., \& Collier, E. J. (1999). United Methodist Clergywomen Retention Study. Anna Howard Shaw Center at Boston University School of Theology. https://www.bu.edu/shaw/publications/the-clergy-womens-retention-study/

Wind, J. P., \& Rendle, G. R. (2001). The Leadership Situation Facing American Congregations: An Alban Institute Special Report. Alban Institute.

Wind, J. P., \& Wood, D. J. (2001). Becoming a Pastor: Reflections on the Transition into Ministry Report. The Alban Institute. https://alban.org/uploadedFiles/Alban/Bookstore/pdf/TiMReport.pdf 
Woolever, C. (2012, May 22). What are the consequences of clergy turnover? (Part 2). https://presbyterian.typepad.com/beyondordinary/2012/05/what-are-the-consequences-of-clergyturnover-part-2.html

Zikmund, B. B., Lummis, A. T., \& Chang, P. M. Y. (1998). Clergy Women: An Uphill Calling. Westminster John Knox Press. 